\title{
Mining for Greenlandic self-government: Fractal islands in the Anthropocene
}

\author{
Frida Hastrup \\ University of Copenhagen, Denmark \\ hastrup@hum.ku.dk \\ Nathalia Brichet \\ University of Copenhagen, Denmark \\ nathalia.brichet@sund.ku.dk
}

\begin{abstract}
This article explores the emergence of Greenland as an Anthropocene island through anthropological fieldwork in and around the decommissioned Nalunaq goldmine in the south of the country. The article takes off from the idea that Anthropocene activities are characterized by the invention, movement, and marketing of seemingly mobile resource units that can be identified and invested in regardless of landscape specificities, and explores how the production of Greenlandic gold complicates this idea of extraction. In particular, the article discusses how Greenlandic post-colonial independence and ambitions for mining both go together and undermine each other, creating new dependencies and relationalities along the way. Through analyzing parts of Nalunaq's political context, infrastructural challenges, the gold that came out, and eventual closure, the article presents Greenlandic gold mining as a set of partly congruous, partly contradictory practices and ideas. The article thus specifies an extractive project that both is and is not possible on the world's biggest island, and brings this to bear on how we might understand the Anthropocene.
\end{abstract}

Keywords: Anthropocene, de-soilization, fractality, gold, Greenland, independence, islandness, island sovereignty, mining.

https://doi.org/10.24043/isj.166 • Received October 2020, Early access July 2021

(C) Island Studies Journal, 2022

\section{Introduction: Greenland as a mining island}

What might a story about Greenland as an Anthropocene island look like? In this article, we respond to this question through anthropological fieldwork in and around the goldmine Nalunaq in South Greenland from 2013 onwards. What we present here is primarily an ethnographic account about Nalunaq, engaging particular aspects of the context in which it worked, how it operated practically, what it produced, and, eventually, how it closed down. Our fieldwork story probes Greenland as a mining island and, in particular, how Greenlandic post-colonial independence and ambitions for mining both go together and "mock" each other (Strathern, 1987, p. 286). 
During fieldwork, ambitions for independence and mining were continuously related and portrayed as interdependent. By following these cues that related mining and independence, however, it became clear that these two features of Greenlandic society are not at all reducible to each other. Rather, looking at Greenlandic mining as means to selfgovernment made intriguing fragilities of both ambitions emerge. The article inserts itself in these fragilities, and, in the following, we thus describe partly overlapping, partly contradictory practices and ideas related to the goldmine, with the overall aim of evoking Nalunaq as a Greenlandic specification of an extractive project that both is and is not possible on the world's biggest island.

Before doing this, we will present some conceptual and theoretical points of departure regarding our approach to the Anthropocene, Greenland, mining, and island relationality, thereby explaining how this article's analytical nexus is crafted.

\section{The Anthropocene as 'de-soilization'}

Much can be and has been said about the notion of the Anthropocene (see, e.g., Crutzen \& Stoermer, 2000; Lewis \& Maslin, 2015; Haraway, 2015; Hastrup \& Lien, 2020). These debates are interesting and highly important across a number of disciplines, most notably for pointing out that the current era is the result of unevenly distributed resource practices, rather than caused by an undifferentiated human species. However, in this article, the aim is not to go into definitional problems, nor to discuss the purchase of the concept itself or of the suggested alternatives. Here, we simply approach mining as a distinct Anthropocene activity, characterized by what philosopher of science Bruno Latour (Latour et al., 2018, p. 592) has referred to as a "de-soilization" of the land. This implies a historically specific set of modernist practices that attempt to appropriate land as if the land were not there, imagining it solely as an inanimate background for resource exploitation (Latour et al., 2018, p. 592). Such desoilization, then, indicates a particular vision of humans being able and entitled to move organisms and objects around the world at will, to harvest them as assets, and to market them as products (see, e.g., Tsing, 2015; Crosby, 1972). While this articulation of the Anthropocene is not meant to defuse political contest and historical tensions in the context of Greenlandic mining, working from this particular notion of the Anthropocene as desoilization allows us to suggest that the 'islandness' of Greenland is both absolutely vital and merely circumstantial for the Nalunaq goldmining project, and to make this our specific contribution to research on the nature of islands in the Anthropocene. Put differently, our claim is this: if de-soilization is a heuristic for Anthropocene activities, one might say that all mining projects wherever they take place create 'islands' - de-soilized entities defined, extracted, and globalized regardless of specific lands of origin. In this sense, actual island geography is not important for a given mining project. However, in the case of Greenland, the specificities of a particular and ambiguous relation to Denmark as well as challenges posed by infrastructure, weather, logistics, and the like vastly complicate this Anthropocene desoilization, whereby Greenland's islandness becomes an essential feature of mining. Indeed, as will become clear, Nalunaq is not just 'anywhere', and the Nalunaq mining operation kept facing insurmountable operational problems. Accordingly, our approach is warranted by the ambiguous ways that Nalunaq gold materialized both a set of marketable and discrete units 
with no particular provenience and an object of intense relation-making within and beyond dichotomous post-colonial connections.

De-soilization is often characterized by a disjunction between the interests of distant global investors who design the movable units on the one hand, and the richness and unruliness of the landscapes they invest in on the other. This figure of the distant versus the proximate, well-known to island scholars (see, e.g., Baldacchino, 2020), is thus also central for understanding Anthropocene practices. Anthropologist Anna Tsing (in Latour et al., 2018, p. 594) puts it like this:

The ability of those investors to shape the fate of whatever kind of assemblage that is juxtaposed there - to change it completely, to wipe it out - is an effect that we have to be willing to look at in a relationship between 'the far-off' and 'the closeto' in order to understand.

Our fieldwork in and around Greenlandic mining is one way of substantiating this challenge; what emerge here are particular and intriguing configurations of distant and close, and an island geography that kept appearing and disappearing.

\section{Island relationalities in Greenland}

We combine the articulation of the Anthropocene as characterized by de-soilization and faroff visions of resource units with the recent focus on relationality in islands studies (Pugh, 2018). Scholarship on islands has shown that any island comes into its own as much through connections with other places as by being a separate entity. This further complicates practices of de-soilization; no matter the ambitions to appropriate land regardless of land, the relations that any island is, has, cuts off, and engenders still matter. This is perhaps a particularly crucial observation with regard to mining in Greenland, given that this endeavor is often seen by politicians and others as a means of becoming a global mining country and of finally achieving proper independence of Denmark, Greenland's former colonizer (see, e.g., Nuttall, 2017; Grydehøj, 2020).

To sum up so far, in the article we thus work from an idea about the Anthropocene as a troublesome assumption of discrete and moveable resource units, and we take Greenland to be a relational unit that is co-produced by the island's paradoxical connections to the rest of the world, including Denmark. Importantly, as already indicated, this is not an article primarily about colonial and post-colonial relations between Greenland and Denmark. It is a fieldworkbased analysis of Greenland's versatile attempts at becoming an economically sustainable nation under self-government, which is then brought to bear on the ways that the Anthropocene is both an era of seemingly de-soilized entities and of intense relation-making - a finding which again has a bearing on how we can understand the 'islandness' of Greenland.

In further engaging relationality as an inherent feature of Greenland as a global mining actor, we draw on anthropologist Marilyn Strathern's (see, e.g., 2004) theorization of relations. Strathern's characteristically enigmatic analytic provides an anti-totalizing approach to ethnographic descriptions, positing that the social relations ethnographers study always produce new and more relations. In terms of probing Greenlandic mining relationalities, what particularly interests us here is Strathern's suggestion that whatever the anthropologist's scale 
of observation, the level of complexity of the fieldwork material is constant. She puts it like this: "As we sift through the contexts and levels of our materials, we find that enlarging or diminishing this or that set of problems does not seem to increase or decrease the complexity of the information itself' (Strathern, 2004, p. 108). Whether one zooms in close on a detail or zooms out to a perceived societal whole, the picture is equally complex and equally partial. Strathern (2004) proposes that such a 'fractal' (see also Pugh, 2018, pp. 99-100) image is an effect of ethnographic inquiry; regardless of how one zooms in or out, no holism can be arrived at, and no totalizing point of view applies. Whether we explore Nalunaq from afar, for instance by looking at how it is seen to engender national sovereignty, or from up close, looking at the flora surrounding the mining camp, the point here is that these fractal perspectives are not additive and differently sized parts of a whole. Rather, the different points constitute Nalunaq, all while mocking attempts at understanding and describing this in any totality or from a privileged point of view.

Importantly, we argue that this is not just an academically intriguing or methodological challenging point. Indeed, the fractal analytic of Greenland as a mining actor, we suggest, is also an empirical matter, as the Nalunaq goldmine both is and is not co-extensive with Greenlandic ambitions of mining for self-government.

\section{Structuring a fieldwork description of Nalunaq}

In terms of structuring our fieldwork account and of selecting which elements to include, in the following, the zooming maneuver often found in ethnographic accounts is both mimicked (by moving from global to local level observation) and mocked (by seeing these viewpoints as non-additive and of equal 'size'). We thus describe bits of our fieldwork not as parts of Greenlandic mining as a whole, but as a set of partial analytical incisions. More concretely, we start our fieldwork account on the national scale, exploring how an independent nation gets articulated and envisioned through both a Greenlandic political mining strategy and through so-called fact-driven scientific geological mappings and assessments of the investment climate in Greenland. Here, we focus on the ways that mining ambitions and ambitions for post-colonial sovereignty go together, in the process producing both national independency (while maintaining tight relations to Denmark) and new connections with other countries. We then move on to address whether and how this national ambition of mining for independence played out regionally at the location where distant investors hit the ground. Here, we argue that the Nalunaq goldmine can be seen, at best, as a very unruly realization of the visions of national sovereignty. This particular mine, we show, emerged as an island on the island that required intense and difficult movement of equipment, people, and resources. Thereby, the national entity seems less central than local infrastructural and management issues regarding, in particular, the moving around of soil and other substances. In this section, we mainly engage with Nalunaq employees and conversations in the mine, and the main point is to show that crafting independence through mining in a place as 'remote' - even from the national capital — as Nalunaq creates a series of other dependencies on foreign expertise, imported infrastructure, and shipped-in goods. In the next section, we concentrate on the product of gold from Nalunaq and explore how this is a distinctly local product with particular qualities, all while being a stable base metal to be marketed and valued as a de-soilized entity. By drawing on discussions within the (Danish) jewelry sector, as they 
were articulated to us during fieldwork, we look at the 'byproducts' of pure Greenlandic gold: among other things, how complex democratic and royal relations between Greenland and Denmark are melted into gold from Nalunaq. Finally, and in conclusion, we look at what Nalunaq left behind after it ceased operation in 2013 in response to sudden unfavourable conditions on the world market and the intensely expensive nature of mining in a place like Nalunaq. We do this by focusing on the grounded practices of clearing the mine according to environmental assessment, and by discussing the figure of the local entrepreneur working in a precarious time in the life of Greenlandic mining. We discuss these practices of closing down as instantiations of precarity in the Anthropocene when practices of de-soilization continuously depend on local relational assemblages of landscapes, people, and more-thanhuman actors. The mining project, then, is not even co-extensive with itself, but depends on its significant others. This is not least important in a mining setting where being a relatively distant island and a distinct national territory afford a sense of singularity all while operating through a particular partnership with Denmark, among others.

Importantly, we do not change between these scales and elements in our ethnographic material in order to simplify or complicate, as if one example could somehow correct or complete another. Rather, the proposition of 'fractality' as a characteristic of Greenlandic mining is a way of ethnographically evoking partial and provisional Greenlandic mining practices and, thus, of exploring Anthropocene islands - big and small.

\section{Projecting underground riches: Mining for national independence}

In Greenland, the 2013 election campaigns featured lively discussions about oil, gas, and mineral potentials. When the winner of the election, the first female premier in Greenland, Aleqa Hammond, took office, her government was quick to sign an exploitation license with a Chinese company intending to establish a large-scale mine to exploit iron in the Nuuk Fjord (Sejersen, 2018). That same year, she also made the controversial decision to cast a vote in the Greenlandic parliament, which with a narrow majority resulted in a lift of the ban on uranium mining in Greenland (Bjørst, 2017). Hammond's politics were conceived shortly after the adoption of the 2009 Self-Government Act, granting Greenland self-government as a member of the Kingdom of Denmark, also comprising the Faroe Islands (Adler-Nissen \& $\mathrm{Gad}, 2017)$. In other words, the time was ripe for Greenland pressing on an agenda of independence from its former colonizer, Denmark. In her New Year's speech, Hammond (2014) declared that her government's activities for mining were necessary in order to take action and implement the spirit of the self-government; the population could no longer lean back and expect independence to come by itself. Courage to make big decisions was needed and she was proud to lead this process, as she said (Hammond, 2014). The spirit of independence of which Hammond spoke should, at least partly, be actualized through mining (Nuttall, 2017; Grydehøj, 2020). According to the Greenlandic government's strategy plan for 2014-2018, the Ministry of Mineral Resources aimed to open three to five mines and two to four off-shore drilling projects by 2018. The logic behind these mining ambitions was clearly that economic independence would lead to political independence; in Greenlandic politics, these two features are often seen as mutually constitutive (Grydehøj, 2020, p. 106). In particular, the Danish state's annual block grant of around 483 million Euros was simultaneously discussed intensely in both Denmark and Greenland. Financing one third of 
the Greenlandic economy and 60\% of the self-government's public budget (Rosing et al., 2014, p. 25), the block grant contributes significantly to the island's welfare. But with high hopes invested in near-future subsoil projects, scenarios of ending the controversial Danish grant were imagined and formulated, as discussed in a highly profiled university report, for example, as we shall elaborate below.

In the Self-Government Act, the jurisdiction over the subterranean resources of the island was one of the first fields of responsibility that was transferred to the Greenlandic people. Seemingly, at the point in time when the Self-Government Act was formulated, the expectations of what mining could yield were unlimited. As a corollary to the juridical transfer, it was therefore agreed that the block grant be frozen at the then-current level, and that any profits from subterranean resource extraction would be balanced against this grant according to complicated calculations (Grydehøj, 2020). What is interesting here is that mining and the expected revenues from it are described as a direct means towards national self-government. As Grydehøj (2020, p. 95) puts it, "one result of the way in which the SelfGovernment Act was constructed has been to create a conceptual association between independence and extractive industries (especially mining)."

In the years after the Self-Government Act, public discussion about Greenlandic mineral potentials was intense. Prompted by this interest, the University of Greenland (in Nuuk) and the University of Copenhagen established the Committee for Greenlandic Mineral Resources to the Benefit of Society, the final result of which was a report titled To the Benefit of Greenland (Rosing et al., 2014). The aim of the committee was to scientifically qualify, contextualize, and substantiate the often quite heated debate about the potentials of the world's largest island's natural mineral resources. The work of the committee, then, was to establish the facts that would enable political decisions. In the report, it is phrased like this: "The aim has not been to create new research but to collect existing information in a range of fields in order to provide an overall view of the challenges related to this complicated issue, as well as potential solutions" (Rosing et al., 2014, p. 5). What we note here is the ambition to provide an "overall view", heeding all existing research. Scientific facts and attendant scenarios to choose from, it seems, will enable political decision-making. Interestingly, the complex relation between Greenland and Denmark is explicitly mentioned as a background for the report, stating that it answers to a need for a sound and facts-based discussion about the potentials of Greenlandic minerals for bringing about (further) independence from Danish subsidies. The preface by the rectors from the two universities concludes as follows:

The outcome [of the committee work] is a comprehensive survey of the challenges and opportunities natural resources present [to] the people of Greenland. We hope that this report about the socially beneficial use of Greenland's natural resources will be a useful source of information for decision makers in Greenland and Denmark. In addition, we hope that it will contribute to broad, public discussion about a highly important issue affecting the future of Greenland and the Kingdom of Denmark. (Pars \& Hemmingsen in Rosing et al., 2014, p. 4)

What particularly interests us in this scientific review of Greenlandic mineral resources is that relations to Denmark are so present in the very act of assessing Greenland's mineral potential. In other words, the two national units come to life together, even in a work 
answering to a need to review Greenland's underground riches and attendant potential for independence from Denmark. Or, as one of the lead authors has it, the report "lists proposals for how the mineral natural resources can be used to benefit Greenland and Greenlanders as much as possible and thereby also benefit the Kingdom of Denmark as a whole" (Rosing et al., 2014, p. 6). The potential benefits for one country are directly connected to benefits for the other. This connection between Greenland and Denmark, as captured in the report's references to the Kingdom of Denmark, in fact, also caused debate within the committee so much so that one committee member, Icelandic professor of Polar Law Gudmundur Alfredsson, eventually chose to express clear dissent in the final report (Alfredsson in Rosing et al., 2014, p. 48).

Hammond and the Committee are not alone in charting a Greenlandic mineral future. Indeed, mining for Greenlandic self-government is a global affair - networks and resources beyond Greenland (and Denmark) are needed. Accordingly, attending the annual meeting of the Prospectors and Developers Association in Canada (PDAC) in Toronto is a must for people working with the Greenlandic mining industry. Every year, delegations from both Greenland and Denmark travel to Toronto with their bags full of drill cores, rock samples, colorful posters, business cards, and hopes of somehow making a good deal. Dreams are formulated, numbers presented, networks created, and agreements negotiated. One of us (Brichet) had the opportunity to attend the conference in 2014. The former Deputy Minister for Energy, Industry and Trade, Jørn Skov Nielsen, opened the Doing Business and Investing in Greenland session by stating that, like elsewhere, the mineral sector in Greenland was hit by the financial crisis; but he also pointed to an ongoing "positive development." He then listed all the projects that were in the pipeline and how the Department of the Ministry had worked to lift a ban on uranium, open new areas for exploration, and make special rules to accommodate large-scale projects. From his presentation, it was clear that the government envisioned a unidirectional path towards facilitating an extraction industry. The CEO for the Greenland Business Association also chipped in, stating that "lots of things had happened in Greenland since last PDAC." Among other things, the CEO said that Greenland has gotten global attention and is now at a "stage where we can call ourselves a mining country; we are ready!" After this and a few other pep-talks, Kenneth Green from the Canadian Fraser Institute took the microphone. The room became highly attentive; in a few seconds, Mr. Green would reveal the ranking of Greenland as a mining country, the main role of the Fraser Institute being to annually rank countries and regions according to the extent to which their jurisdictions and geology encourage or discourage mining investments - an event which is always reported in Greenlandic media and which featured regularly in fieldwork conversations. Green opened by introducing the Fraser Institute as an independent agency, then turned to the ranking process where he stressed the importance of "getting the policy right." After this, he announced that Greenland had ranked $23^{\text {rd }}$ out of 112 measured countries. People murmured in the room. Then, he explained that this was a nine step decline compared to the year before - and, again, stressed the importance of stability, predictability, and transparency. After this announcement, a CEO from an exploration company raised his voice and said, "I love the Fraser Institute, but they are being too hard on Greenland." To this Mr. Green replied, "We don't fill in the numbers, that's miners around the world don't shoot the messenger." Merely a messenger, the Fraser Institute embodies the notion that mining potentials can be objects of the kind of de-soilization mentioned above, through 
the work of translating local circumstances into measurable factors that can be compared across national borders. In other words, in order for Greenland to become a globally important mining actor, prospering without Danish custody, it is necessary to rely on a Canadian think tank (and their processing of input from miners who bother to reply to their questionnaire), which relays the country's attractiveness for mining in a number — changeable every year.

What we see here, then, are different assessments of the Greenlandic mining climate as a way to self-government (Hammond, 2014), as a comprehensive scientific and nonpolitical examination (Rosing et al., 2014), and as a measurement of the factors that matter to mining attractiveness (Fraser Institute, 2021). Taken together, these assessments show how mining for independence comes to life along with new sets of dependencies - on Denmark and in the wider world. Greenland, then, is an island of mining in the midst of global streams. Further, the hopeful or, at least, facts-based or numerical projections of national riches still need to be pursued in actual practice - in the soil. In the next section, we move on to exploring one such operation, the Nalunaq goldmine in South Greenland, to investigate how the visions of national economic growth and independence played out in a specific region.

\section{Moving in and out of Nalunaq: Regional mining infrastructure}

The mountain that became the Nalunaq goldmine is located in a distant valley 30 kilometres from the small town Nanortalik in South Greenland; a trip by plane, helicopter, boat, and car away from the capital Nuuk - weather permitting. The name Nalunaq is Greenlandic and means "the place that is difficult to find." When it was finally discovered (as a mountain hosting gold in supposedly commercially profitable amounts, that is) in 1992, the place was suddenly less remote - at least from some points of view. Ensuing activity, including the establishment of a mining camp to house just over one hundred people and a nine-kilometre gravel road from the dock to the camp and mine, led to the opening of the first goldmine in the country in 2004 (Boertmann, 2018). At first, extracting the gold implied shipping tons and tons of blasted ore body first to a processing plant in Spain and, later, to a plant in Newfoundland and Labrador, Canada. In this initial period of operation from 2004 to 2009, 19 kilometres of tunnel were drilled inside the host mountain and eight tons of gold were extracted (Bach, 2020, p. 15). This was no small infrastructural maneuver, which goes to show that high hopes (and willing investors, no less) were in place, and that the grade of gold was considered exceptionally good - good enough to warrant this massive and costly movement of heavy Greenlandic matter across the globe. However, the distance between the gold's place of origin and the processing plants that were needed to infuse Greenlandic gold into the world market was eventually complicit in putting an end to the mining company that had initially established Nalunaq. In 2009, new investors assembled at the Toronto Venture Stock Exchange, making it possible for another company to acquire the mine. To prevent costly shipping of heavy ore body, this new owner constructed a local processing plant inside the increasingly hollowed-out Nalunaq mountain. From then on, only gold doré should leave the mine; tailings were stored underground in the mined-out areas. The new company produced over two tons of gold between 2011 and 2013, but eventually they, too, ran into financial difficulties and were forced to stop the operation in 2013. When the mine closed down, a total of 10.67 tons of gold had been extracted from around 713.000 tons of 
ore (Bell et al., 2017), a good portion of which was shipped out of Greenland for processing, as noted above.

During our first fieldwork in Nalunaq proper (a 10-day stay in the camp in September 2013), we talked with employees from all over the world who arrived with the single purpose of working in the mine and who were ready to move on when resources ran out and investors directed their attention to other places and opportunities. Miners from Cornwall (UK) whose fathers, grandfathers, and great-grandfathers had worked in British coal mines now teamed up with a Lithuanian mechanic, an Icelandic safety instructor, Greenlandic drivers, and an Irish overseer, all of whom relied on Chinese drilling equipment, German bobcats, and, not least, the working experiences from other mines across the globe. A few Danes were also employed, some of whom had transferred from the first company settled at Nalunaq, retained for purposes of local institutional memory. About half of the staff were Greenlanders, including the trained kitchen employees, a nurse, and a large group of unskilled Greenlandic youth from the nearest southern towns and villages. Almost all of these people worked in shifts of six weeks (of six working days) alternating with three weeks off at home. This organization entailed a heavy traffic - and intense observations of the weather forecast - in and out of the geographically remote mine, as people, spare parts, expertise, and eventually gold left or arrived. On the ground, here, we wondered how this was a Greenlandic mine at the service of national independence. Regional effects were pointed out to us; income from taxation of both national and international employees had helped fund a home for elders and a sports facility in the nearby town of Nanortalik. Further, the mine had also created jobs in the region, otherwise severely hit by unemployment, especially after the fish factory in Nanortalik had closed down. While Nalunaq thus had some obvious material effects in its vicinity, what was striking was the massive transit in and out of people, equipment, and provisions. For all of the geological potentials and relative political stability of Greenlandic mining politics, as demonstrated by the assessments discussed above, the particular mine of Nalunaq and its entourage seemed only to be passing through. Once it was known that Nalunaq was coming to a close, workers started looking around for jobs. One worker, Paul, was interviewed online for a job in a mine in Congo; the taxation, he told us, was much lighter than in Greenland, but he was worried about the working conditions. Per, a young local from Nanortalik in charge of logistics and the warehouse for the mine's equipment, considered joining the US Thule Air Base in the far north of Greenland or maybe getting a degree that could qualify him for future jobs. Ole, the Greenlandic chef, went on to manage a hotel kitchen "up north", where he was originally from, and later became a traveling chef on large fisheries vessels. Working as kitchen hands for a couple of days during our fieldwork, we discussed his work in the mine's kitchen. Ole seemed mildly disappointed that the local Greenlandic foods were not enough sustenance for the crew of international miners; jokingly, he complained about having to serve more imported pork than local fish. Bottles of Worchestershire sauce with a never-ending shelf life were lined up in the kitchen storeroom, apparently needed to cater to international tastes.

What we show here is that, during our visit to Nalunaq, the national project of crafting independence from Denmark faded from view. Instead, the place emerged as crosscut by a host of other dependencies and "freedoms", having to do with people in transit, moving objects, international palates, and - eventually - the economic unsustainability of the ambition to infuse Greenlandic gold into the world market. The Anthropocene de-soilization 
of materials was both accomplished and impossible; Greenland was both one and many islands. Zooming in closer, the very product to come out of the mine, the Greenlandic gold, too, recast the national connections and independencies in interesting ways, to which we turn in the following.

\section{Producing local gold: A unique noble metal}

Shortly after the Nalunaq mine began producing gold, it was announced that the wedding rings uniting the Danish Crown Prince Frederik with the princess-to-be had been minted from the first gold bar ever extracted from the Greenlandic underground. Traditionally, there has been a strong bond between the Greenlanders and the present members of the Danish royal family. Many Greenlanders have a lot of affection for the Royal family, and vice versa. The fact that the Crown Prince has served in the Sirius Dog Sled Patrol, a highly specialized Danish military unit patrolling the uninhabited northeastern part of Greenland by dog sled for the purpose of ensuring territorial sovereignty, has only earned him more popularity. The gold for the wedding rings was a gift from the home-rule government (before the acquisition of self-government in 2009) presented on behalf of the Greenlandic people. When getting wind of this gift and the relation between Greenlandic gold and the Danish royalty, the Danish jeweler Nicolai Appel saw an opportunity to "democratize the royal gold," as he later told us, and to make it available, or at least known, to a bigger audience. While gold is of course not exactly a commonly accessible good, Appel saw a potential for popularizing the product through these links between the two countries. To Appel, there was simply a very good story in gold from Nalunaq; its traceability to a particular mountain and its connection to the popular Danish Royal Court had potential. Thus, he contacted the National Bank of Denmark and the CEO from the goldmine to ask if they could help reserve some of the gold from the mine and market it as "Greenlandic gold" instead of selling it off to be merged with gold from elsewhere, which is usually what happens when gold is turned into a globally standardized product. In the beginning, Appel had a hard time convincing colleagues, economists, and miners about this idea of distinctly Greenlandic gold. They commented that this intervention would raise the production price and, eventually, also the selling price. "Why all this fuss?", they asked, "after all, gold is gold" - a base element born with stable qualities and a value that works as a universal standard. But for Appel, gold was not just gold. He put it like this in a Danish newspaper:

When you buy a piece of jewelry in Greenlandic gold, you get a clear location on the map and certainty about where it is from and how it is produced. It is dignified gold. The idea behind this is similar to that of Max Havelaar's products. As a consumer you are assured that a proper price has been paid for the product and that fair production conditions prevail, and you also support an indigenous people. Such certainty has never before applied to gold - on the contrary. Normally, gold is a stock item just like a piece of plywood. (Appel in Tjørring, 2006, p. 6)

Fairtrade certifications like that launched by Max Havelaar are usually born out of a critique of the systematic underpayment and disempowering of workers in low-income countries (see, e.g., Waldmeier, 2013). Greenland, however, is not considered a low-income 
country with disempowered and underpaid workers. Following a Danish welfare state model, Greenlandic workers are well-organized in unions, and wages are high compared to those in low-income countries and even compared to standards in other European countries. In addition to well-regulated and organized production conditions in Greenland, Appel also ascribed importance to the gold's geographical origin in his work to single out Greenlandic gold, which to him was anything but a de-soilized entity. Formally reassuring production circumstances was not enough to make "dignified gold," as Appel put it. Why not make local traceability part of the base element and protect the product under the national name of Greenland?

To Appel, and, eventually, his colleagues, the idea that Greenlandic gold is of a particular quality needed to be made visible. In order to distinguish it from "stock items", Appel designed a polar bear - also visualized in the Greenlandic (and Danish) coat of arms - to be stamped into jewelry made from Greenlandic gold. Soon, the master of the guild in Copenhagen and Royal Danish Court jeweler, who also made the royal wedding rings, approved the idea (Tjørring, 2006, p. 6). Following this, polar bear-stamped Greenlandic gold became a relatively popular product in both Nuuk, where a Danish jeweler worked with it, and in Denmark among a handful of interested jewelers. The perceived singularity of Greenlandic gold caught on - instantiated again through ties to the Royal Danish Court. In 2012, Appel was part of a delegation handing over a gift from the people of Greenland to the Danish Queen Margrethe on the occasion of her $40^{\text {th }}$ anniversary as a regent. The delegation was led by the head of the Greenlandic parliament who, on behalf of the Greenlanders, presented her with a gift: a diadem and earrings made by Appel from Greenlandic gold, picturing motifs of Arctic flora. In a Greenlandic newspaper, the handing over of the gift was framed in the following way by the then-chairman of the Greenlandic parliament, Josef Motzfeldt (as quoted in Thorsen, 2012):

I hope your Majesty will receive the gift as a sign of gratitude for your never faltering interest in our country and people [...] And allow me to say that your love for Greenland and the Greenlanders is absolutely reciprocated by the people.

According to the journalist covering the event, the Queen was moved upon receiving the gift and confirmed her love for Greenland: "Yes. And thank you very much. Greenland and its people have always had a special place in our hearts" (as quoted in Thorsen, 2012).

What we see here, again, are two nations, politically organized in a welfare-based federation (the Kingdom of Denmark) that somehow melt into each other through the very distinct national features of each - the royalty of one and the distinct local base rock of the other. Interestingly, there is seemingly no contradiction in construing mining as a means of achieving independence from Denmark and popularizing the product of Greenlandic mining through ties to the Danish royal family.

These ties were once again made visible in 2014, when mining activities in Greenland were largely on hold due to uncertainties about the global market (see, e.g., Boertmann, 2018). At this time, Crown Prince Frederik became a leading figure in the Greenlandic delegation at the annual PDAC congress mentioned above. His presence was seen as one of the most efficient means for winning back lost terrain and improving the attractiveness of Greenland as a mining region. Our point here is that Greenlandic gold, aided by the 
connection to the Royal Danish Court that curiously brought gold closer to the people of both countries, emerged as a particular and local material impressed with particular democratic values (such as union rights), welfare benefits (such as proper wages and tax-paid provisions), and ethical standards (such as environmental control). In this way, the polar bear stamp on the Greenlandic gold simultaneously came to produce Greenland as a singular and certified gold mining site, yielding a democratically sound product, all while confirming ties to the Danish elite. What we point to here is that the Nalunaq goldmine was, in a way, "close enough" to the people of both countries for them to pay more for its product than for other gold, due to an intriguing mix of elitist exclusivity and popular notions of social fairness as embedded in, for example, proper working conditions. Again, ideas about distance, proximity, and ownership in the relations between Denmark and Greenland mock each other, as do ideas about what and who can be seen to govern the Kingdom of Denmark. Certainly, thinking about this as an issue of post-colonial independence in any straightforward way seems to miss the mark.

\section{Closing time: A Nalunaq Anthropocene}

In late 2013, Nalunaq closed its operation as it was no longer economically sustainable. The decommissioning entailed a cleaning up and restoration process lasting until August 2014 (Bach, 2020). The Danish Agency for Environment and Energy (DCE) together with the Greenland Institute of Natural Resources (GINR) were in charge of monitoring and approving the process, as is stipulated in the current Greenlandic law on mineral extraction (Boertmann, 2018). One of us (Brichet) had the opportunity to follow the small group of people from DCE and GINR on their first fieldtrip after the mine had closed. For a week, samples were taken from water, mussels, and soil, and waste was considered. The overall process of closing was discussed along a number of parameters, all while a cleaning up and nature rehabilitation program was carried out by a local entrepreneur who owned the necessary machinery. Just after the snow had finally melted from the Nalunaq valley, the entrepreneur had stationed around 10 workers to remove traces of the camp and the mining operation. Two main environmental risks of the mining operation were identified; one related to the potential spreading through dust and water of released metals from the processing and transport of rock, and one related to the discharge of residues of cyanide used in the Nalunaq processing facility to liquefy gold particles for their extraction. In response to these potential risks, an environmental monitoring program was set up (Bach, 2020, p. 5). The program did not find any alarming impacts to the environment but only "moderate pollution" and "minor impacts". The process was summarized as follows:

In general, relatively few pieces of waste/scrap were localized in the terrain and it is assessed that it does not pose any risk to the environment, but that the impact is related solely to esthetical matters. Overall, DCE assesses that the current environmental impact from the former mining activities to the environment at Nalunaq is insignificant and that no further actions are needed to reduce the environmental impact. (Bach, 2020, p. 2) 
For the team responsible for the environmental agency's cleaning up program, the environmental impact from the Nalunaq goldmine could be seen as insignificant - a mild case. This was also pointed out during concrete activities of cleaning up in the valley; Nalunaq was a minor and well-regulated mine compared to other places. But, as the team in agreement with the local workers also stressed, the mining activity was not insignificant in relation to the social and economic impact in the region. So even though two successive mining companies could not make ends meet, there seemed to be general satisfaction with the Nalunaq operation having provided both jobs to the region and tax income to the local municipality - at least for a time, as we shall return to later.

These positive vibes notwithstanding, the clean-up after the mining activities spurred interesting discussions both among the small group of biologists and chemical specialists and among the local workers. During the week at the field site, we talked about what kind of society Greenland should be - locally, nationally, and internationally — and trade-offs for mining. What was foregrounded were discussions about the acceptable price for generating gold, about the means by which a society should live in the future, and about balancing environmental sustainability and the quest for independence - much like the issues discussed in the Greenlandic parliament. Here in the former goldmine, it played out materially through blasted detonating cords, oil-polluted soil, employment policies, (industrial) tourism, cyanide, mussels, lichens, and so on. Considerations, pros and cons, and decisions were discussed in the small team, while the workers relocated the flow of a small river to avoid leaking of heavy metals from the former settlement pond. Soil was moved, stuff was burned, and the camp taken apart. Finally, all of the entrances to the mine were closed off. During the week, it became clear which of the mining traces in the valley needed further action and which parts could stay where they had been abandoned. Every now and then, the word "rehabilitation" was mentioned. Sometimes this implied an ideal of bringing the mined area back to its original state; sometimes complete rehabilitation was considered impossible, since so much rock had been blasted, crushed, removed and spread out over the area. In practice, rehabilitation consisted in the task of reducing and controlling further damage. At times, this meant leaving visible traces of the industrial activities as a kind of lesser evil.

For example, when looking into the soil where the former generator had been located, the specialists found that oil had been spilled and that the soil and gravel were thus polluted. Something had to be done to prevent oil from slowly seeping into the river system, potentially spreading uncontrollably. After some discussion about whether to ship the oil-polluted soil to a clean-up facility 3000 kilometres away in Southern Denmark or to put the heavy load into one of the mine's abandoned galleries for eternity, the latter solution was agreed upon. After all, a lot of fuel would be needed to ship the heavy load to distant Denmark, and the option was not considered worthwhile. Inside the mountain, the relocated soil could be placed on a heavy-duty tarp that, according to the scientists, would last many thousand years and prevent spilling over. On location, this was considered a more secure way of dealing with the traces of the Nalunaq mine.

Once the last remaining constructions of the camp had been dismantled, the ground laid bare. At first glance, it looked nice and tidy - even beautiful with the purple lupines blossoming on the outskirts of the camp ground; indeed, the place seemed to have been returned to its state before the mine. But, then again: the lupines had been brought to the site by a woman who had worked in the mine's lab and who had made her own small garden by 
planting lupine seeds. Lupines are invasive in Greenland and, as such, were not part of the flora in the valley before she brought them. According to the biologist from the monitoring team, they would spread and, via their nitrogen binding qualities, they might alter conditions for future flora in the valley, just like they had done in a village some 100 kilometres away where they had also been introduced by humans. "Ethically," they should be removed, another scientist said; but, "aesthetically," they should stay since they made for a pretty purple sprinkle in the rocky landscape. On this location, an invasive newcomer brought from elsewhere by a mining employee was considered compatible enough with the local landscape. At least, removing the lupines was considered too much of an effort, since the flowers had already invaded the country. Not that the DCE does not care for the local flora. Indeed, the cover of their concluding report (Bach, 2020) shows a beautiful photo of a Broad-leaved willow herb - the national flower of Greenland - on a background of untouched mountains in the valley of Nalunaq, thereby closing the life of the mine by indirectly asserting that its operation was minute and insignificant compared to the still-pristine Greenlandic nature around it. The mine, it seemed, was too small and distant to matter as an environmental case, but big and proximate enough to benefit society in the region around it.

From up close, though, the stony ground was anything but tidy. Small industrial items became visible. Nails and screws, small broken metallic parts, batteries, caps from drinking bottles, and, not least, the ubiquitous detonator cords: small cords of yellow plastic between 3-40 cm long protruding here and there from the blasted rocks. When blasting tunnels in the mountain to get to the gold-bearing quartz vein, huge amounts of rocks had had to be removed. This waste rock was used to construct the road and camp ground and, as it still contained the blasted pieces of detonator cord, these were scattered all around. We learned that the cords were made of simple polyethylene and, as such, not environmentally damaging. The problem was that they would break down into smaller fragments and microplastics, at which point they risked being ingested or absorbed by animals like birds, foxes, and fish. Long-distance migratory birds in need of food were especially vulnerable, as they could easily mistake the yellow plastic for edibles. In 2013, horrible and worrying images of carcasses of albatross with stomachs full of plastic had begun to emerge on the social media. With these images in mind, the team collected bouquets of yellow cords, even though the task seemed endless. One of the scientists made matters even worse by explaining how the next summer's floods from melting snow would cause even more cords to emerge from the ground, spurring further clean-ups.

The point of presenting the examples of the lupines and the microplastics and birds is to stress the basic insight that the environmental monitors both are and are not in control of ensuring a proper cleaning up after Nalunaq. On the one hand, they make a series of choices (e.g., lupines can stay, polluted soil can be stored in the vacated mine) while, on the other hand, time and non-human actors play their part, potentially spreading microplastics across a vast area. The issue here, then, is that Nalunaq is both a minute and remote mining operation with no local environmental impact to speak of, and a case that illustrates the problems potentially inherent in any practices of de-soilization. Put differently, birds, time, and melting water, too, can move things around, complicating the work of deleting the traces of Nalunaq. Careful environmental monitoring, characteristic of Greenlandic mining and accomplished through a scientific partnership between a Danish and a Greenlandic institution, also implies a host of choices about which baseline to work from when cleaning up. Questions emerge 
about what belongs in this landscape and what needs to be removed and contained. What we suggest here is that any Anthropocene activity, on whatever scale, faces such issues - and, as such, the fact that Greenland is an island is both significant and insignificant. Indeed, if the Anthropocene is captured in the notion of de-soilization, any extractive activity entails the (impossible) fantasy of parceling out islands to be commercialized.

Timescales, too, become paradoxical. An ancient geological gold deposit is mined within a decade, after which environmental monitors decide to leave polluted soil inside the defunct mine for eternity. All the while, plans are being formed to reopen Nalunaq in order to explore surrounding areas for similar gold deposits. The lead actor here - curiously referring to itself as a "first mover in high-grade gold belt" (AEX Gold, 2021) - expresses confidence that the reopening of Nalunaq will be successful not least because the company has bought "geological data dating back to the 1980s" (AEX Gold, 2021). Thus, a generation of data that has so far gone into making the Nalunaq goldmine economically (un)sustainable is now invoked as an argument for the solidity of the future project in Nalunaq. Further, another argument in this work to reopen the extraction of gold, in addition to its high-grade nature, is the view that the area is ice-free all year round, well-connected, and well-accessible, as it is located in between three Greenlandic towns, wired to communication systems and vital infrastructure (AEX Gold, 2021). In arguing for a reopening, the connectivity and, indeed, centrality of Nalunaq is highlighted, contrasting with both DCE's image of a vast untouched nature still in place and with the numerous and massive logistical headaches that we were alerted to during our stay at the mine. According to numerical measures, such as those of the Fraser Institute mentioned above, Nalunaq may seem too good to be true. As Eldur Olafsson, the CEO of the hopeful company who sees a mining future in Nalunaq, has it, "As soon as we have done it once in Nalunaq, we can do it again and again and again" (Ford, 2020). Indeed, it seems that nothing can go wrong with the mine that previously did two mining companies in. After all, the area has one of the highest grades of gold to rock in the world, according to the CEO, making de-soilization seem easy.

The day before we left Nalunaq in its closing weeks in 2013, we talked to the British then-CEO. Puzzled that this high-grade gold mining area could not sustain itself, we naïvely asked who had actually profited from Nalunaq. In reply, the CEO asked if we had noticed the biggest mansion on the hill in the nearby town. This belonged to a local entrepreneur who had rented out machines for the Nalunaq operation and who was later responsible for the cleaning up. Apparently, the British CEO told us, there was little limit to how he could price his services, since he owned the only such necessary machinery in all of the area. The remoteness of Greenland as a mining island reappeared as highly relevant, even though the Icelandic CEO of the next owner stresses the location's connectedness and accessibility. What is interesting here is that this entrepreneur embodies, as it were, the tension that we have addressed all along: Greenland as a mining island is both home to a de-soilized mineral economy ready to compete on a global market, and a scene for the literally very grounded nature of such extraction - where the soil remains unbearably local, one might say. Similarly, the Greenlandic gold oscillated between being a generic stable substance appearing as, for example, high-grade and a particular local Greenlandic product to be further qualified by personified relations with the popular Danish royal family. Scientific facts, too, become both the basis of an unprejudiced discussion about Greenlandic mining and its relations to national independency of Denmark, as we learned above from the report from the University 
Committee, and the sound basis that allows the CEO of the future Nalunaq to trust in the mine's viability. While Nalunaq in the eyes of this optimistic Icelandic CEO is wellconnected and accessible, the very local entrepreneur was indispensable and did not have to offer competitive prices for his services, once again intensely complicating the issue of Greenland's 'islandness' in an Anthropocene era.

The image of the fractal, then, is apparent all the way through. As we have shown, Greenlandic mining emerges as a precarious yet viable business, inscribed into the SelfGovernment Act as a means of independence. It emerges as a remote operation demanding a huge infrastructural and globalized effort, although it is still too small to really matter in terms of environmental impact. In this pristine and vast area, we learn, mining for gold can be done over and over again. And, in the meantime, employees from the now-bankrupt tenders for this golden ore must look for new and possibly equally precarious — or de-soilized employment while the entrepreneur looks out of the mansion on the hill for the next local business opportunity.

\section{Acknowledgments}

We would like to warmly thank the many people who contributed to our fieldwork. In particular, we are grateful to everyone working in and around the Nalunaq mine who allowed us into their offices, tunnels, meetings, houses, and discussions during and after the mine's operation. We are also grateful to Jonathan Pugh and the two reviewers for providing valuable comments. Thanks are also due to Aarhus University Research on the Anthropocene (AURA) and to the Danish Council for Independent Research's Sapere Aude program, which funded the research through the project Natural Goods? Processing Raw Materials in Global Times.

\section{References}

Adler-Nissen, R., \& Gad, U. P. (2017). In the post-colonial waiting room: How overseas countries and territories play games with the norm of sovereignty. In C. Epstein (Ed.), Against international relations norms (pp. 175-192). Routledge. https://doi.org/10.4324/9781315665955-11

AEX Gold. (2021). Projects: Nalunaq. https://www.aexgold.com/projects/nalunaq/

Bach, L. (2020). Environmental monitoring at the Nalunaq gold mine, South Greenland, 2004-2019 (DCE Scientific Report no. 386). Danish Centre for Environment and Energy, Aarhus University. https://dce2.au.dk/pub/SR386.pdf

Baldacchino, G. (2020). How far can one go? How distance matters in island development. Island Studies Journal, 15(1), 25-42. https://doi.org/10.24043/isj.70

Bell, R.-M., Kolb, J., Waight, T. E., Bagas, L., \& Thomson, T. (2017). A Palaeoproterozoic multi-stage hydrothermal alteration system at Nalunaq gold deposit, South Greenland. Mineralium Deposita, 52, 383-404. https://doi.org/10.1007/s00126-016-0667-7

Bjørst, L. R., (2017). Arctic resource dilemmas: Tolerance talk and the mining of Greenland's uranium. In R. C. Thomsen \& L. R. Bjørst (Eds.), Heritage and change in the Arctic: Resources for the present, and the future (pp. 159-175). Aalborg Universitetsforlag. https://doi.org/10.1017/s0032247418000505 
Boertmann, D. (2018). Miljø og råstoffer $i$ Gronland. Aarhus Universitetsforlag.

Crosby, A. (1972). The Columbian exchange. Biological and cultural consequences of 1492. Greenwood Press.

Crutzen, P. J., \& Stoermer, E. F. (2000). The “Anthropocene”. Global Change Newsletter, 41, 17-18.

http://www.igbp.net/download/18.316f18321323470177580001401/137638308845 2/NL41.pdf

Ford, A. (2020, August 13). AEX Gold could have upwards of two million ounces of gold under its belt in Greenland, as it pushes towards first production next year. Proactive. https://www.proactiveinvestors.co.uk/companies/news/926610/aex-gold-couldhave-upwards-of-two-million-ounces-of-gold-under-its-belt-in-greenland-as-itpushes-towards-first-production-next-year-926610.html

Fraser Institute. (2021). Mining research archive. https://www.fraserinstitute.org/archive/categories/171/mining

Grydehøj, A. (2020). Unravelling economic dependence and independence in relation to island sovereignty: The case of Kalaallit Nunaat (Greenland). Island Studies Journal, 15(1), 89-112. https://doi.org/10.24043/isj.101

Hammond, A. (2014). Nytårstale 2014. Naalakkersuisut, Government of Greenland. https://naalakkersuisut.gl/ /media/Nanoq/Files/Attached\%20Files/Taler/DK/Nytaa rstale $\% 202014 . p d f$

Haraway, D. (2015). Anthropocene, Capitalocene, Plantationocene, Chthulucene: Making kin. Environmental Humanities, 6, 159-165. https://doi.org/10.1215/22011919-3615934

Hastrup, F., \& Lien, M. E. (2020). Welfare frontiers? Resource practices in the Nordic Arctic Anthropocene. Anthropological Journal of European Cultures, 29(1), v-xxi. https://doi.org/10.3167/ajec.2020.290101

Latour, B., Stengers, I., Tsing, A., \& Bubandt, N. O. (2018). Anthropologists are talking about capitalism, ecology, apocalypse. Ethnos, 83(3), 587-606. https://doi.org/10.1080/00141844.2018.1457703

Lewis, S., \& Maslin, M. (2015). Defining the Anthropocene. Nature, 519, 171-180. https://doi.org/10.1038/nature14258

Nuttall, M. (2017). Climate, society and subsurface politics in Greenland: Under the great ice. Routledge.

Pugh, J. (2018). Relationality and island studies in the Anthropocene. Island Studies Journal, 13(2), 93-110. https://doi.org/10.24043/isj.48

Rosing, M., Mosbech, A., Hansen, A. M., Mortensen, B. O. G., Ulfbeck, V. G., Alfredsson, G., Sejersen, F., Helgesen, G., Hansen, K. G., Rasmussen, M. V., Borch, O. J., Rasmussen, R. O., \& Nielsen, S. B. (2014). To the benefit of Greenland: The Committee for Greenlandic Mineral Resources to the Benefit of Society. University of Copenhagen.

Sejersen, F. (2018). Scaling sustainability in the Arctic. In U. P. Gad \& J. Strandsbjerg (Eds.), The politics of sustainability in the Arctic: Reconfiguring identity, space and time (pp. 94-107). Routledge. https://doi.org/10.4324/9781351031981-6

Strathern, M. (2004). Partial connections (Updated edition). AltaMira Press.

Strathern, M. (1987). An awkward relationship: The case of feminism and anthropology. Signs: Journal of Women in Culture and Society, 12(2), 276-292. https://doi.org/10.1086/494321 
Thorsen, R. (2012, June 12). Galleri: Det fantastiske diadem af guld til dronningen. Sermitsiaq. https://sermitsiaq.ag/node/128433

Tjørring, R. (2006, October 13). Grønlandsk guld. Berlingske Tidende, Section 4, p. 6.

Tsing, A. (2015). The mushroom at the end of the world. Princeton University Press.

Waldmeier, F. (2013). We are Fairtrade. Max Havelaar Foundation. https://www.maxhavelaar.ch/fileadmin/user upload/publikationen/mh JB2013 e.pdf 